of particular, limited sections or communitios. With the liberating power inherent in science as a spiritual force, clashes and tensions arise which may limit our froedom of choico and action, and this givos the groater strength to the contention horo, as in the Reith Loctures, that not meroly the coming of automation but the whole tendency of the age challonges us to a primary and determined effort of broad education in human values at overy lovel.

\section{EVOLUTION ILLUSTRATED}

\section{Atlas of Evolution}

By Sir Gavin de Boor. Pp. $202+16$ plates. (Edinburgh: Thomas Nelson and Sons; Ltd., 1964.) $90 s$.

T HIS large copiously illustratod book, beautifully designed and printed in Flolland, may suffor tho same fato as somo of its rocent biological congenors and be treated by trade and public alike as a 'coffoe-table' offering. But modern synthoses of wide biological subjects, to be effectivo sciontifically, oducationally and as general stimuli to further reading and onjoymont, must almost invariably come to rosomble 'still' telovision programmos. The bost onos noarly all do; and Sir Gavin de Boor's Atlas, unique, pithy, lucid and scholarly, is almost straight from Channel Two and just the sort of porformance which gets (or entirely merits) a lato-hour repeat on Channel One. It is a tour de force, in fact, of adult education; and should (indeod must) also become prescribed sixth-formlovel reading for all sehools who can afford it, or whose education authorities oncourage advontures with books outsido mainstroam text-books. It is a pattorn, indeed, for the text-book of the future.

In the century of the acceptance and refinement of Darwin's law of the process of evolution by natural selection fow could have brought so much to a synthesis from about soven sphoros of authority as de Boor. Ever since his presidency of the fifteenth, Darwin centennial, International Congross of Zoology, Sir Gavin has obviously belonged to the exclusive kennel of Darwin's pedigree prophet-bulldogs, with the Huxloys, Sir Ronald Fishor, Simpson, Mayr and a very few othors. A polymath of ovolution, ho has distilled for us its philosophical history, and the undorstandings of its process which derive from ecology, systematics, palaeontology, genetics, biochemistry and ombryology. The book is arranged undor the sevoro logic of: What is the situation? How does it work? What do wo loarn from it?; and culminates in a beautifully balanced and up-to-date account of the ovolution of man and his mind.

More than two-thirds of de Boor's Atlas is occupiod by the atlas part; that is to say, pictures, maps and captions. The planning and intogration of such work, two of the most difficult tasks in the world of sorious communication, have been magnificently done, and reflect what was obviously a very close and fruitful relationship betweon the writor and his designer, Mr. J. van den. Bos. The frequent and effoctive use of dramatic images and presentations has nevor boen allowod to looson the book's disciplino. Somo of the atlas material, howover (and its captions), show less precision than the toxt: I guess that some pictures and maps were commissioned, together with the research bohind them, from outside sourcos-not very up to date.

The choice of basic map-projection, though highly ingenious, is not the most suitable ono. I can find no oxplanation in the text of its source or systom, though it appears to be an equal-area projection. It rends the region at present occupiod by the holarctic fauna untimely botween Greenland and Iceland-not ovon down the middle of Greenland, which is the natural boundary of the present nearctic and polearetic sub-faunas. South
America ends up practically as far away from Africa and Australia as it could be: this never should be if the present, or indeed Tortiary, distributions are to be understood at a glance. Zoologists have quite onough problems with continental drift without adding to it. Better would have been (for example) a Fawcott equal-area map based on a London-contred hennisphere with the land masses of the opposite homisphere in petals-alroady widely and usefully adoptod for global distribution plots of terrostrial taxa.

As an atlas merits unusual care in the soloction of projoctions to fit its material, I offer this as a serious advorse criticism, and at the same time my respects to do Beer for the fact that it is the only one I can make of an otherwise almost porfect work of science and art, hand in hand. Other criticisms aro minor, and may refer partly to material of which de Beor may not have had full control. In maps of relict distributions all fossil localities should suroly have boen spotted and not, as many are, indicated as largish hatched aroas. On p. 130 the ratite map missos many opportunitios of clarity and accuracy. The tapir map could have boon made much loss sketchy; it evidently pinpoints but at small sample of fossil sitos of the genus Tapirus (some shown as Pliocene aro surely reforable to early Ploistocene) and would have been much more exciting and informative had it also shown known localities of bones which have boen referred to the genus in, for example, Borneo (prohistoric); Florida, Missouri, South California, Oklahoma, Arizona, Buonos Airos, Argontina, Holland, Italy and Sumatra (Ploistocene); California, Argontina, Poland, Italy, Jugoslavia and Szechuan (Pliocene); Germany (Mioceno); and France, Germany and Switzerland (Oligocenn). There is also a Tortiary fossil tapir site in Bolivia.

Although it does not exactly say so in the caption, the puffin distribution and variation map which demonstrates Borgmann's ecological rule (Plate 10, noar p. 120) gives the impression of a breeding distribution which, if so, is falso. The figuros (p. 109) appoar to dorive from a textbook published nearly half a century ago. Far botter and more up-to-dato maps and discussions were offorod by Salomonsen (including an account of an important 'dwarf-mutation' in some populations) in 1944 and by Lockley in 1953. On the same pago opportunities are missed, through over-simplification and range distortion, of domonstrating that the gull-chain of Larus argentatus and its allies has probably given rise to not two but five valid species since tho retreat of the last Ploistocene glaciation - - a situation, incidontally, picked up in fine dotail on the same seale, by another 'coffee-tablo' book lately publishod.

This roviow is written by an ornithologist, and all specialists can pick on special points in the most careful books of wido scholarship. In such books it is probably wise to follow the consensus of established opinion, to which Sir Gavin do Beer himself has contributod so much and so wisely. However, I find a littlo disappointment in his uncritical quotation of "the cave-paintings of Lascaux, dated by carbon-14 analysis as 15,000 years old" (against a caption on the same page "painted about 20,000 years ago"). In fact, what was dated (Chicago Univorsity tost $406,15,516 \pm 900$ yoars B.P., see Libby in 1963) was charcoal taken from an occupation-level in the cave by Breuil and Blane in 1949. The paintings are of no fauna which could have lived in that part of France thon, though only the lato F. E. Zeuner (and, following him much later, myself) seem to have suggosted that it (and there. fore its painters) may have lived in an interstadial period, perhaps as much as 100,000 years B.P.

Doubtless some map projoctions and presentations, and some facts and opinions, will be ro-assossed in future editions of this work of scholarship and thoughtful synthesis. It is bound to become prescribed roading, in its succeoding editions, for moro than a generation of rising biologists.
JAMES F'ISHER 